HOMECARE AND PATIENT SAFETY

\title{
Homecare Safety Virtual Quality Improvement Collaboratives
}

Wayne Miller, Maaike Asselbergs, Jeanne Bank, Mike Cass, Virginia Flintoft and Nadine Henningsen

\begin{abstract}
With Canada's aging population, innovations in technology and changes in patient preferences regarding where they receive care, there is a growing reliance on homecare services. Professionals in the homecare sector want to provide the best care possible for their clients, whereas homecare organizations look to foster a greater patient safety culture. The Canadian Patient Safety Institute and the Canadian Home Care Association conducted two learning collaboratives aimed at increasing quality improvement capability in homecare settings. Teams from across the country have increased their capacity and capability to engage patients and families, mitigate and prevent harm from homecare safety incidents such as falls and specifically address issues such as improving interprofessional collaboration, teamwork and communication.
\end{abstract}

\section{Background}

Homecare is a fundamental part of our healthcare system and has the potential to impact patient outcomes and healthcare sustainability. At some point in their lives, many Canadians will find themselves either giving or receiving homecare. Within an integrated healthcare system, homecare provides essential services that encompass health promotion and teaching, curative intervention, end-of-life care, rehabilitation, support and maintenance, social adaptation and integration and support for the family caregiver. Homecare is a priority for all Canadians - for patients and their carers, for healthcare providers and for governments (CHCA et al. 2016).

Homecare is an extremely diverse and unstandardized sector, in terms of its patient population, services offered and geographic coverage. Providing safe care in an unpredictable and/or inconsistent home setting poses unique challenges that require the engagement and active involvement of professional care providers, clients and family caregivers.

The Safety at Home homecare study examined adverse events in the home and provided recommendations on how to make care safer (Doran et al. 2013). Dr. Diane Doran, co-lead Dr. Régis Blais and their team spent 2 years examining administrative databases and reviewing charts across the country that showed that the reported rate of adverse events in Canadian homecare clients was 10 to $13 \%$ over a period of 1 year (Doran et al. 2013). If their findings were extrapolated to reflect the over one million homecare recipients in Canada, this could mean that approximately 130,000 Canadians experienced an adverse event during the study period (Doran et al. 2013). The authors found that half of these adverse events were preventable. Given the large number of Canadians being served by the homecare sector every day, improvements in its quality of care have the potential to make significant contributions to improving overall healthcare performance. 


\section{Addressing Adverse Events in Homecare}

The Canadian Patient Safety Institute (CPSI) recognizes the importance of providing safe and effective care in the home setting. Between the fall of 2015 and the spring of 2018, CPSI and the CHCA partnered with a variety of organizations and homecare agencies to offer two different learning collaboratives referred to as Wave 1 and Wave 2. These learning collaboratives were modelled after the Institute for Healthcare Improvement (IHI) virtual learning program - the IHI collaborative model (for more information, see Appendix 1; available at: https://www.longwoods.com/content/26042) (IHI 2003). Both Wave 1 and Wave 2 were structured virtual learning programs that addressed quality improvement and patient safety practices.

In November 2015 Wave 1 was launched and was a partnership between CPSI, CHCA and the Canadian Foundation for Healthcare Improvement (CFHI). In Wave 1 all participating teams focused on fall prevention (KD Consulting 2016). The year-long Wave 1 collaborative engaged five homecare organizations with the broad goal of reducing falls in the homecare setting. All teams participated in interactive learning sessions, outcome measurement, coaching and group quality improvement discussions. The primary change drivers were a combination of foundational education on the key principles of quality improvement and intensive one-on-one coaching. Each team had a patient or family member who was directly involved as a patient or family advisor on each team.

In February 2017, CPSI and CHCA introduced Wave 2 of the collaborative with the goal of further enhancing quality improvement within the Canadian homecare sector and increasing the capacity of homecare organizations to engage in future patient safety work. Seven homecare teams completed the Wave 2 collaborative, which concluded in February 2018. The improvement collaborative included education sessions on theories of quality improvement, homecare and patient safety, interprofessional collaboration, the management of effective teams, measuring and obtaining data for improvement, patient and family engagement, project charters, quality improvement tools and run charts. Teams completed a patient safety pilot project on a topic chosen by their organization and were supported by coaches from CPSI and CHCA throughout the collaborative (for more information, see Appendix 2; available at: https://www.longwoods. com/content/26042).

\section{Methodology}

For the safety projects, each organization had an executive sponsor, who maintained a connection between the project team and the organization's leadership. The teams were composed of a lead (or two co-leads), a data management person and two other team members. Each team had weekly meetings with a coach from CPSI or CHCA, who helped guide teams through the different phases of the pilot projects. Project topics were selected by each organization, based on its needs and priorities. Selecting the topic for the pilot project was a change from the Wave 1 collaborative, where all organizations worked on fall prevention. The aim of having organizations select their own topics was to lead to better organizational engagement and a greater impact on clients.

Formal evaluations were prepared for both Wave 1 (KD Consulting 2016) and Wave 2 (Lennika Consulting Inc. 2018) of the virtual quality improvement collaboratives. Wave 1 was evaluated through key informant interviews and observations of the final collaborative event held in March 2016. Semi-structured interviews were conducted with participating teams and the team involved in implementing the collaborative (steering committee, coaches, external consultants, etc.), both at two points during the collaborative. In addition to the in-depth qualitative methodology, key documents, event recordings and outcome data were reviewed to look for patterns and variations. The information contributed to telling the story of each team's journey in the collaborative and gave insight into successes and challenges. A brief case study for each participating organization was compiled based on the data collected through interviews, observations and document reviews.

According to Yin (2003), a case study design should be considered when: (a) the focus of the study is to answer "how" and "why" questions; (b) the intention is not to manipulate but to understand the behaviour of those involved in the study; and (c) you want to cover contextual conditions because you believe they are relevant to the study. This process sewed together the richness of individual team stories, experiences and outcomes in order to capture a bigger picture of the value and full impact of the collaborative.

A "realist evaluation framework" (Pawson and Tilley 1997) was undertaken to find out how the outcome of the collaborative was shaped, enabled and constrained by the interactions between the context (the participant's organizational setting and external constraints) and the mechanisms (the stakeholders' ideas about how the change will be achieved through this approach) (Greenhalgh et al. 2009). This approach helps develop and improve the content and targeting of future programs.

The evaluation of the Wave 2 collaborative included a survey of all participants, key information interviews and a review of the resources and materials used during the collaborative. The evaluation focused on the quality of the educational content, participant satisfaction and the impact of the collaborative on the participants, the homecare organizations involved and the care of their clients. The main elements of the evaluation framework included descriptive information about 
the organizations involved and the pilot projects they undertook, information regarding their level of engagement with the Wave 2 process and the impacts of the collaborative on both client outcomes and the safety culture of the organizations. A data collection strategy was developed to obtain information on each element of the framework.

\section{Patient Engagement}

Engaging patients and families in fall risk assessment and prevention was one of the goals identified for the Wave 1 collaborative. Patient engagement was not just about consultation but also about early and direct involvement in conversations about improvement so that solutions are derived from actual experience versus perceived notions of health providers and leaders. Participating teams were encouraged to identify a patient or patient carer as an advisor to participate as an active team member. This was the first time many of the organizations had involved a patient and family advisor (PFA) in a quality improvement initiative. For most of the teams, the independent evaluator found that patient and family engagement was a positive experience.

Many of the PFAs struggled with the virtual Internetbased nature of the learning sessions because of a lack of experience with technology or issues of access in their home environment. Going forward, it was recognized that a more structured approach, including training and resources for teams, patients and families, was required so that PFAs could take full advantage of the opportunity. Recommendations to better support the PFAs included an orientation to healthcare delivery processes, the philosophy of quality improvement and expectations of the role.

One of the learning sessions during the Wave 2 collaborative focused on patient and family engagement from theory to the front line. However, it was still difficult to truly capture and embed the patient/client voice in the improvement projects. One of the recommendations from the Wave 2 evaluation was for more focus on greater involvement from patient or carer, while recognizing that such relationships take time and can be difficult for short-term projects.

\section{Outcomes}

\section{Wave 1 fall prevention collaborative}

Each of the five teams participating in Wave 1 had unique contexts and circumstances that impacted their quality improvement journey. A key component of the coaching was to ensure that the support provided to teams addressed their unique needs and allowed them to move at their own pace. Although some teams were able to define and reach laudable improvement goals, for others, the development of their baselines was most valuable. The collaborative provided teams with the impetus and momentum they needed to look at their data and apply change strategies and systematic data analysis to engage front-line staff and address gaps in practice.

The collaborative assisted teams in meeting fall-related required organizational practices for accreditation. It also reinforced the national homecare safety priority articulated in Better Home Care in Canada: A National Action Plan, released by CHCA, the College of Family Physicians of Canada and the Canadian Nurses Association in 2016, which stated that supporting the principles of patient- and family-centred care can be a key mechanism for improvement in these areas in the future (CHCA et al. 2016). The Wave 1 approach was an effective method for connecting teams across the country, assisting organizations with identifying areas for improvement and developing reproducible measurement strategies.

Organizations involved in the quality improvement collaborative experienced the following value from their participation:

- Identified local issues and larger system barriers to reducing preventable harm in the home

- Shed light on current understanding of and assumptions about care delivery processes, staff knowledge and patient education resources

- Engaged system partners (contract providers) in accessing relevant data and collaborative care planning

- Implemented small changes that resulted in big improvements

- Involved patients and families in practical and meaningful ways

- Achieved a better understanding of the time and resources needed to sustain change and the important role of senior leadership to make this happen

- Empowered front-line staff and brought awareness to their role in creating and sustaining change

Homecare is not delivered in a bricks-and-mortar building and as such brings its own unique set of nuances in terms of context and mobilizing teams toward improvement goals. Using the realist framework, the evaluation of Wave 1 looked at content, intended mechanism and outcome. The evaluation findings reflect the following:

- During the relatively short duration of Wave 1 , the collaborative was able to help teams show a reduction in falls in small pilot samples of their client populations. The teams were able to sustain the improvements and create active plans for spread.

- The collaborative was successful in helping organizations identify areas for improvement, scope their aim statements, identify measurement requirements and choose tailored 
change strategies. Many teams said that being part of the collaborative gave them the momentum they needed to get the very important work of reducing falls started.

- Satisfaction with different components of the collaborative program varied, but, overall, teams were happy to have participated and felt it had been a valuable endeavour for their organizations.

- The collaborative was successful in drawing attention to the benefits of engaging clients and families for quality improvement. Each team engaged patient advisors in their project; however, the experience was variable given the nature of the program, and some felt the role and purpose of patient engagement needed more clarity and structure to be effective.

- Pre-collaborative readiness assessments may be useful in determining varying starting points and availability of data for all teams to avoid assumptions that may cause delays.

- Ensuring that teams understand that identifying emergent learning opportunities may be just as important as defining and meeting loftier improvement goals.

- A more structured approach to the collaborative could include resources such as a guidebook or training materials for teams and interventions to address the barriers to the patient's and the family's greater participation.

Based on Wave 1 feedback, key improvement suggestions for the Wave 2 rollout included the development of a change package (Box 1) to centrally share best practices with new teams and increased training and resources related to effective client and family engagement in quality improvement.

BOX 1.

Change package

- A suggested approach for the future might be to create a "change package," which can be updated over time with participating teams.

- This could help new teams select priority focus areas and get ideas for tests of change.

- The package could also include a menu of potential improvements, strategies, specific validated tools and outcome measures that any team could begin piloting.

See Appendix 1 for a summary of the Wave 1 participants and their goals and outcomes.

\section{Wave 2 collaborative}

Wave 2 of the homecare safety improvement collaborative was a structured learning program that facilitated collaboration and knowledge application to address common homecare safety issues. The collaborative involved education sessions on topics relevant to quality improvement in the homecare sector and the completion of a patient safety pilot project. The entire collaborative was delivered virtually through online sessions, teleconferences and online chatrooms. It ran from February 15, 2017, to February 21, 2018. Optional coaching was offered for up to an additional 6 months to interested teams.

Over the first half of the collaborative, the educational sessions were delivered by topic experts on roughly a biweekly basis. Following the presentations, participants would conduct a post-learning online huddle to discuss their learnings and questions. Coaches would immediately respond to questions posted on the Share Hub site, where collaborative materials were housed. In the Wave 2 evaluation, the quality of the coaching received an average score of 5.78, presentation an average score of 5.95 and other resource material a score of 5.61 on average (all on a scale of 1 to 7 , with 7 being the highest rating). See Box 2 for a list of the strengths and challenges identified in the evaluation.

\section{BOX 2.}

Strengths and challenges of Wave 2 collaborative

\section{Strengths}

- Access to quality improvement tools

- Seeing other quality improvement approaches in action

- Access to coaching expertise

- The quality of the expert presenters

- Ability to focus on completing a single project

- Opportunity to work as teams

- Opportunity to get feedback from peers across the country

- Allowing the teams to select their own pilot project ideas

- Ability to leverage/use collaborative resources going forward

\section{Challenges}

- Balancing other work priorities

- Insufficient time/time pressures

- Insufficient involvement from some executive sponsors

- Inadequate early planning and preparations by teams

- Difficulties defining a project idea/aim statement

- The need for more time for individual presentations at the final meeting

- Difficulties using and navigating the share information hub

- Data are not used enough in the homecare sector

Participants in Wave 1 included the Canadian Red CrossCornwall, Saint Elizabeth Health Care, Winnipeg Regional Health Authority, VHA Home HealthCare and Eastern Health Authority (NL). Seven homecare organizations completed the Wave 2 collaborative: Beacon Community Services (BC), Care at Home Services (BC), CBI Health Group (Canada-wide), Central West Local Health Integration Network Home and Community Care Access Centre (ON), Nova Scotia Health Authority (NS), Vancouver Island Health Authority (BC) and VHA Home HealthCare (ON). Spectrum Health (ON) began the collaborative but ended its involvement early in the process due to competing organizational priorities. 
The safety projects focused on a wide array of client populations and care requirements, including client-centred dementia care, infection surveillance and management of central and peripheral lines, reducing the negative impacts from repeat patient falls and improving documented interventions for reported falls. See Appendix 2 for a summary of the homecare organizations participating in Wave 2 and their safety projects.

The Wave 2 collaborative was generally seen as working well and an improvement on the Wave 1 initiative. In terms of the amount of time participants spent on the Wave 2 collaborative, $33 \%$ reported less than 10 hours per month, $28 \%$ reported 11 to 20 hours per month, $33 \%$ spent 21 to 40 hours and $6 \%$ spent more than 40 hours (Figure 1). Some $72 \%$ of participants rated the amount of time they spent on the collaborative as "about the right amount of time," with $22 \%$ feeling they spent too little time and the remaining $6 \%$ reporting that they spent too much time on the initiative.

\section{FIGURE 1.}

Time spent on the collaborative (hours/months)

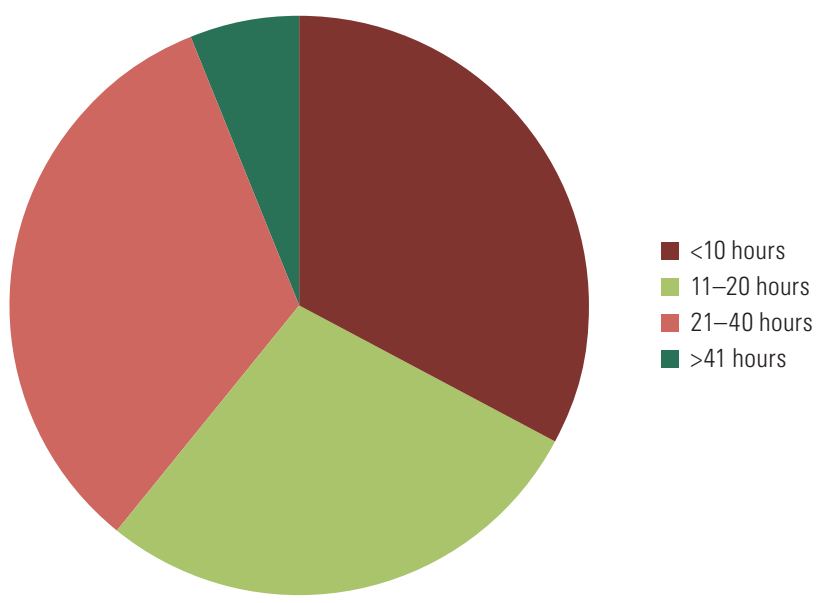

The Wave 2 collaborative was designed to encourage both interprofessional collaboration within teams and learning across teams. The expert presentations addressed the topics of interpersonal collaboration and the creation of effective teams. Teams in the collaborative were provided with several opportunities to present their pilot projects to all participants at various stages, to receive feedback and learn about the work being conducted by other teams. Most participants were quite positive in their overall assessment of the collaborative, with one participant noting, "It was a positive experience which led to improvement for the team and organization."

Access to quality improvement tools, methodology and seeing other quality improvement approaches in action were identified as positive impacts by several participants. One participated noted that "the coaching provided a level of consult/expertise that would not have been available/accessible to our organization otherwise." Another participant remarked on being "inspired by many of the guest speakers and their work."

When asked to rate their personal satisfaction with the collaborative overall, $87.5 \%$ of respondents scored 5 or above (on a scale of 1 to 7 , with 7 being the highest rating), with an average score of 5.46. Most participants noted that the collaborative would help them in meeting future accreditation standards. Some $50 \%$ of respondents said they would participate, again, and $73 \%$ of respondents said they would recommend that their organization participate in a similar initiative in the future.

\section{Conclusion}

Key aspects of the collaboratives, including the quality of the coaching, the quality of the expert speakers and the level of intra-team and across-team learning, were viewed positively by participants. The Wave 2 collaborative was generally seen as an improvement over the Wave 1 initiative. Allowing teams to select their own area of safety priority was a strength of Wave 2.

Recommendations to be considered in a subsequent Wave include: engaging executive sponsors more in the process; including up to three in-person meetings to improve the connection with and between teams and coaches; greater involvement of patients and family representatives; more work around identifying topics and current capacity for the proposed work before the start of the collaborative; and expanding the length of the collaborative to 18 months to complete projects.

CPSI and CHCA will continue to champion safe care in the home setting and provide service providers with the presentation content and resources created through the homecare safety improvement collaboratives as a stand-alone resource for homecare organizations interested in enhancing their quality improvement and patient safety capacity. $\mathrm{HQ}$

\section{References}

Canadian Home Care Association (CHCA), College of Family Physicians of Canada and Canadian Nurses Association. 2016, October. Better Home Care in Canada: A National Action Plan. Retrieved July 9, $2019<$ https://www.cna-aiic.ca/-/media/cna/page-content/pdf-en/ better-home-care-in-canada_a-national-action-plan-copy.pdf?la=en $\&$ hash=D7C8B69F4E0B000F74CE372D6DAFCA9D198ADD39>.

Canadian Patient Safety Institute (CPSI). 2017, February 15. Eight Canadian Home Care Organizations Pioneering Home Care Safety Improvement. Retrieved July 9, 2019. <http://www. patientsafetyinstitute.ca/en/NewsAlerts/News/newsReleases/Pages/ Eight-Canadian-home-care-organizations-pioneering-home-caresafety-improvement.aspx>.

Doran, D.M., R. Blais, M.B. Harrison, J.P. Hirdes, G.R. Baker, A. Lang et al. 2013. Safety at Home: A Pan-Canadian Home Care Safety Study. Edmonton, AB: Canadian Patient Safety Institute. Retrieved July 9, 2019. <http://www.patientsafetyinstitute.ca/en/toolsResources/ Research/commissionedResearch/SafetyatHome/Documents/ Safety\%20At $\% 20$ Home\%20Care.pdf>. 
Greenhalgh, T., C. Humphrey, J. Hughes, F. Macfarlane, C. Butler and R. Pawson. 2009. How Do You Modernize a Health Service? A Realist Evaluation of Whole-Scale Transformation in London. Milbank Quarterly 87(2): 391-416. doi:10.1111/j.1468-0009.2009.00562.x.

Institute for Healthcare Improvement (IHI). 2003. The Breakthrough Series: IHI's Collaborative Model for Achieving Breakthrough Improvement. IHI Innovation Series White Paper. Boston, MA: Author. Retrieved July 9, 2019. <http://www.ihi.org/resources/ Pages/IHIWhitePapers/TheBreakthroughSeriesIHIsCollaborative ModelforAchievingBreakthroughImprovement.aspx $>$.

KD Consulting. 2016. Final Evaluation Report: CPSI Virtual Quality Improvement Collaborative in the Home Care Sector. London, ON: Author.

Lennika Consulting Inc. 2018. An Evaluation of the Virtual Homecare Safety Improvement Wave 2 Collaborative.

Pawson, R. and N. Tilley. 1997. Realist Evaluation. London, UK: Sage.

Yin, R.K. 2003. Case Study Research: Design and Methods (3rd ed.). Thousand Oaks, CA: Sage.

\section{About the Authors}

Wayne Miller, BPE, BEd, MSc, is senior program manager of the Canadian Patient Safety Institute and the primary lead for homecare safety initiatives.

Maaike Asselbergs is a member of Patients for Patient Safety Canada. Maaike was a member of the Home Care Safety Action Group of the National Patient Safety Consortium.
Jeanne Bank is project lead of the Home Care Knowledge Network, Canadian Home Care Association. Jeanne has project/ program manager experience with a focus on health, safety and social policy areas and is a standards professional at national and international levels.

Mike Cass is senior program manager of the Canadian Patient Safety Institute and has led national-level safety improvement projects and quality improvement collaboratives in medication safety and fall prevention and quality improvement in homecare.

Virginia Flintoft, BN, MSc, is senior program manager at the University of Toronto's Institute for Health Policy, Management and Evaluation. As manager of the Canadian Patient Safety Institute's Central Measurement Team, Virginia is the measurement and evaluation expert, contributing to many quality improvement initiatives.

Nadine Henningsen is chief executive officer of the Canadian Home Care Association. As CEO, Nadine leads a dynamic association dedicated to advancing excellence in homecare through leadership, awareness, advocacy and knowledge.

Correspondence may be directed to: Wayne Miller, Senior Program Manager, Canadian Patient Safety Institute; phone: 709-730-0864; e-mail: wmiller@cpsi-icsp.ca. 


\section{Projets collaboratifs virtuels pour I'amélioration de la qualité des soins à domicile}

Wayne Miller, Maaike Asselbergs, Jeanne Bank, Mike Cass, Virginia Flintoft et Nadine Henningsen

\section{Résumé}

Avec le vieillissement de la population canadienne, les innovations technologiques et les préférences des patients quant au lieu où ils obtiennent des soins, on a de plus en plus recours aux services de soins à domicile. Les professionnels du secteur des soins à domicile souhaitent fournir les meilleurs soins possibles à leurs clients, tandis que les organisations de services à domicile cherchent à promouvoir une culture de la sécurité des patients. L'Institut canadien pour la sécurité des patients et l'Association canadienne de soins et services à domicile ont organisé deux projets d'apprentissage visant à accroître la capacité d'amélioration de la qualité dans les soins à domicile. Partout au pays, des équipes ont renforcé leur capacité à mobiliser les patients et leurs familles, à atténuer et à prévenir les incidents liés aux soins à domicile, tels que les chutes, et à s'attaquer à des problèmes tels que l'amélioration des collaborations interprofessionnelles, du travail d'équipe et de la communication.

\section{Contexte}

Les soins à domicile constituent un élément fondamental du système de santé et peuvent avoir une incidence sur les résultats pour les patients ou sur la durabilité des services de santé. Tôt ou tard, de nombreux Canadiens se verront donner ou recevoir des soins à domicile. Dans un système de santé intégré, les soins à domicile comprennent la promotion de la santé, l'éducation, les interventions curatives, les soins de fin de vie, la réadaptation, le soutien et la maintenance, l'adaptation et l'intégration sociales ainsi que le soutien aux proches aidants. Les services à domicile constituent une priorité pour tous les Canadiens : les patients, les proches aidants, les fournisseurs de soins de santé et les gouvernements (CHCA et coll. 2016).

Les soins à domicile constituent un secteur extrêmement diversifié et non normalisé, notamment pour ce qui est des populations de patients, des services offerts et de l'étendue géographique. Fournir des soins sécuritaires dans un environnement familial imprévisible ou incohérent pose des défis uniques qui nécessitent l'engagement et la participation active des prestataires de soins professionnels, des clients et des proches aidants.

Une étude sur la sécurité des soins à domicile s'est penchée sur les événements indésirables qui surviennent à domicile et présente des recommandations sur la manière de rendre les soins plus sécuritaires (Doran et coll. 2013). Les Drs Diane Doran et Régis Blais, ainsi que leur équipe, ont passé deux ans à examiner des bases de données administratives et des dossiers médicaux dans tout le pays. Ces données montrent que le taux d'événements indésirables signalés dans le contexte des soins à domicile au Canada était de 10 à $13 \%$ sur une période d'une année (Doran et coll. 2013). Si on rapporte ces chiffres au million de bénéficiaires de services à domicile au Canada, 
environ 130000 Canadiens auraient subi un événement indésirable au cours de la période de l'étude (Doran et coll. 2013). Les auteurs ont constaté que la moitié de ces événements indésirables étaient évitables. Étant donné le nombre important de Canadiens desservis quotidiennement par le secteur des soins à domicile, une amélioration de la qualité de ce type de soins pourrait contribuer grandement à l'amélioration du rendement global des services de santé.

\section{Aborder la question des événements indésirables dans les services à domiciles}

L'Institut canadien pour la sécurité des patients (ICSP) reconnaît l'importance de fournir des soins sécuritaires et efficaces à domicile. Entre l'automne 2015 et le printemps 2018, l'ICSP et l'ACSSD se sont associés à diverses organisations et agences de soins à domicile pour mener deux projets collaboratifs d'apprentissage, désignés sous les noms de premier et deuxième volet. Ces collaborations ont été modelées sur le programme d'apprentissage virtuel de l'Institute for Healthcare Improvement (IHI) (pour plus d'informations, voir l'Annexe 1; disponible sur: https://www.longwoods.com/ content/26042) (IHI 2003). Les premier et deuxième volets étaient des programmes d'apprentissage virtuel structurés qui abordaient les pratiques d'amélioration de la qualité et de sécurité des patients.

Le premier volet a été lancé en novembre 2015. Il s'agissait d'un partenariat entre l'ICSP, l'ACSSD et la Fondation canadienne pour l'amélioration des services de santé (FCASS). Toutes les équipes participantes se sont concentrées sur la prévention des chutes (KD Consulting 2016). Cinq organisations de soins à domicile ont été mobilisées dans le but de réduire le nombre de chutes à domicile. Toutes les équipes ont participé à des séances d'apprentissage interactives, à la mesure des résultats, à l'encadrement et à des discussions sur l'amélioration de la qualité. Les principaux moteurs de changement étaient une combinaison d'éducation de base sur les principes d'amélioration de la qualité et un accompagnement individuel intensif. Chaque équipe comptait sur un patient ou un membre de la famille qui était directement impliqué en tant que conseiller.

En février 2017, l'ICSP et l'ACSSD ont lancé le deuxième volet du projet collaboratif dans le but d'améliorer davantage la qualité des soins à domicile et d'accroître la capacité des organisations de services à domicile d'œuvrer à la sécurité des patients. Sept équipes de soins à domicile ont participé au deuxième volet du projet, qui a pris fin en février 2018. Cette collaboration comprenait des séances de formation sur les sujets suivants : théories de l'amélioration de la qualité, sécurité des soins à domicile et des patients, collaboration interprofessionnelle, gestion d'équipes efficaces, mesures et obtention des données d'amélioration, engagement des patients et familles, chartes de projet, outils d'amélioration de la qualité et graphiques de séquence. Par ailleurs, les équipes menaient un projet pilote sur un thème choisi par leur organisation et bénéficiaient d'un accompagnement de la part de de l'ICSP et de l'ACSSD tout au long de la collaboration (pour plus d'informations, voir l'Annexe 2; disponible sur: https://www.longwoods.com/ content/26042).

\section{Méthodologie}

Pour ces projets, chaque organisation comptait sur un gestionnaire qui agissait comme promoteur de projet en assurant le lien entre l'équipe et les dirigeants de l'organisation. Les équipes étaient composées d'un responsable (ou deux coresponsables), d'un responsable de la gestion des données et de deux autres membres. Les équipes se réunissaient chaque semaine avec un accompagnateur de l'ICSP ou de l'ACSSD, qui les guidait dans les étapes du projet pilote. Les thèmes des projets ont été choisis par les organisations en fonction des besoins et priorités. La possibilité de choisir un thème constituait un changement par rapport au premier volet, où tous les organismes travaillaient sur la question de la prévention des chutes. L'idée derrière la possibilité de choisir un thème était de favoriser l'engagement organisationnel et d'avoir un plus grand impact sur la clientèle.

Des évaluations formelles ont été prévues pour le premier volet (KD Consulting 2016) et pour le deuxième volet (Lennika Consulting Inc. 2018). Le premier volet a été évalué au moyen d'entretiens avec des informateurs clés et d'observations lors du dernier événement de la collaboration, en mars 2016. Des entrevues semi-structurées ont été menées auprès des équipes participantes et de l'équipe responsable de la mise en œuvre de la collaboration (comité de pilotage, accompagnateurs, consultants externes, etc.). Ces entrevues ont été menées à deux reprises au cours du projet. Outre la méthodologie qualitative approfondie, des documents clés, des enregistrements d'événements et des données sur les résultats ont été examinés pour déceler les tendances et les variations. Ces informations ont contribué à illustrer le parcours de chaque équipe et à donner un aperçu des succès et défis rencontrés. Une brève étude de cas pour chaque organisation participante a été compilée à partir des données recueillies lors des entretiens, des observations et de l'analyses des documents.

Selon Yin (2003), le modèle d'étude de cas doit être envisagé lorsque : (a) l'objet de l'étude est de répondre aux questions «comment » et " pourquoi »; (b) l'intention n'est pas de manipuler mais de comprendre le comportement des personnes impliquées dans l'étude; et (c) on s'intéresse aux conditions contextuelles parce qu'elles semblent pertinentes pour l'étude. Ce processus a permis de dégager la richesse du parcours, de l'expérience et des résultats des équipes, brossant ainsi un tableau plus complet de la valeur et de l'impact de la collaboration. 
Un " cadre d'évaluation réaliste " (Pawson et Tilley 1997) a été mis en place pour déterminer comment les résultats de la collaboration étaient influencé par l'interaction entre le contexte (le cadre organisationnel des participants et les contraintes externes) et les mécanismes (le point de vue des partenaires sur la mise en œuvre du changement grâce à cette approche) (Greenhalgh et coll. 2009). Cette approche permet de développer et d'améliorer le contenu et le ciblage d'éventuels programmes.

L'évaluation du deuxième volet comprenait un sondage auprès de tous les participants, des entretiens avec des informateurs clés et un examen des ressources et du matériel utilisés. L'évaluation a porté sur la qualité du contenu éducatif, la satisfaction des participants ainsi que l'impact du projet sur les participants, sur les organisations de soins à domicile et sur les soins prodigués à la clientèle. Les principaux éléments du cadre d'évaluation comprenaient des renseignements descriptifs sur les organisations et les projets pilotes qu'elles avaient entrepris, de l'information quant à leur degré d'engagement et quant aux impacts de la collaboration sur les résultats des clients et sur la culture de sécurité des organisations. Une stratégie de collecte de données a été élaborée pour obtenir des informations sur chacun des éléments du cadre d'évaluation.

\section{Engagement des patients}

Faire participer les patients et leurs familles à l'évaluation et à la prévention des risques de chute était un des objectifs du premier volet de la collaboration. L'engagement des patients ne concernait pas seulement la consultation, mais aussi la participation précoce et directe aux discussions sur l'amélioration, de sorte que les solutions découlent de l'expérience réelle et non en fonction de notions perçues par les dirigeants ou les prestataires de services de santé. On incitait les équipes à nommer un patient ou proche aidant comme conseiller et comme participant actif. C'était la première fois que de nombreuses organisations impliquaient un conseiller patient ou proche aidant dans une initiative d'amélioration de la qualité. L'évaluateur indépendant a constaté que la participation des patients et familles était une expérience positive pour la plupart des équipes.

Nombre de conseillers patients ou proches aidants ont eu du mal avec l'interface virtuelle en raison d'un manque d'expérience en matière de technologie ou de problèmes d'accès. On reconnaît qu'une approche plus structurée, comprenant de la formation et des ressources pour les équipes, les patients et les familles, serait nécessaire pour que les conseillers patients ou proches aidants puissent tirer pleinement parti de cette occasion. Les recommandations visant à mieux soutenir les conseillers patients ou proches aidants comprennent des séances d'orientation sur les processus de prestation des services de santé, sur la philosophie d'amélioration de la qualité et sur les attentes envers leur rôle.
Une des séances d'apprentissage du deuxième volet portait sur l'engagement des patients et familles, et ce, de la théorie au travail de terrain. Cependant, il demeure difficile de véritablement capter et intégrer la voix des patients dans les projets d'amélioration. Une des recommandations retenues du deuxième volet est de mettre davantage l'accent sur une plus grande implication des patients ou proches aidants, tout en reconnaissant que de telles relations prennent $\mathrm{du}$ temps et peuvent être difficiles dans le cadre de projets à court terme.

\section{Résultats \\ Premier volet collaboratif : prévention des chutes}

Les contextes et circonstances de chacune des cinq équipes participant au premier volet étaient distincts et cela a eu une incidence sur leur parcours d'amélioration de la qualité. Un élément clé de l'accompagnement consistait à s'assurer que le soutien fourni aux équipes répondait à leurs besoins spécifiques et leur permettait de progresser à leur propre rythme. Bien que certaines équipes aient été en mesure de définir et d'atteindre des objectifs d'amélioration louables, pour d'autres, le développement des bases de référence a été très précieux. La collaboration a fourni aux équipes l'élan et la dynamique nécessaires pour examiner leurs données et appliquer des stratégies de changement et une analyse systématique des données afin de mobiliser le personnel de première ligne et de combler les lacunes de la pratique.

La collaboration a aidé les équipes à se conformer aux pratiques organisationnelles requises en matière de prévention des chutes, et ce, pour obtenir l'agrément. La collaboration appuyait également la priorité nationale en matière de sécurité des soins à domicile énoncée dans le Plan national pour de meilleurs soins à domicile, publié en 2016 par l'ACSSD, le Collège des médecins de famille du Canada et l'Association des infirmières et infirmiers du Canada. Cette priorité stipule que l'appui des principes de soins centrés sur les patients et familles est un mécanisme clé pour l'amélioration dans ces domaines (CHCA et coll. 2016). L’approche empruntée pour le premier volet constitue une méthode efficace pour relier les équipes d'un bout à l'autre du pays, en aidant les organisations à identifier les domaines propices à l'amélioration et à développer des stratégies de mesure reproductibles.

Les organisations ayant participé à l'expérience du projet collaboratif ont obtenu les résultats suivants :

- Identification des enjeux locaux et des barrières du système qui posent obstacle à la réduction des préjudices évitables à domicile

- Nouvel éclairage sur la compréhension des processus de prestation des soins, des connaissances du personnel et des ressources éducationnelles offertes aux patients 
- Participation des partenaires du système (prestataires de services) à la cueillette des données pertinentes et à la planification des soins

- Mise en ouvre de petits changements qui ont eu un impact majeur

- Participation concrète et active des patients et familles au projet

- Meilleure compréhension du temps et des ressources nécessaires pour soutenir le changement et constatation de l'importance du rôle des cadres supérieurs dans l'atteinte de résultats

- Mobilisation du personnel de première ligne dans l'instauration d'un climat de changement durable

Les soins à domicile ne sont pas dispensés dans un établissement officiel et, du fait même, comportent des nuances particulières en matière de contexte et de mobilisation des équipes pour atteindre les objectifs d'amélioration. Pour l'évaluation du premier volet, le cadre réaliste utilisé a permis d'évaluer le contenu, les mécanismes prévus et les résultats. Les conclusions de l'évaluation amènent les points suivants :

- Pendant la durée relativement courte du premier volet, le groupe de collaboration a été en mesure d'aider les équipes à réduire le nombre de chutes auprès de petits échantillons pilotes de leur clientèle. Les équipes ont pu maintenir ces améliorations et créer des plans actifs de diffusion.

- La collaboration est parvenue à aider les organisations à identifier les domaines à améliorer, à définir leurs objectifs, à identifier les exigences en matière de mesure et à choisir des stratégies de changement adaptées. Plusieurs équipes ont déclaré que leur participation à la collaboration leur avait donné l'élan nécessaire pour commencer le travail de réduction des chutes.

- La satisfaction à l'égard des différentes composantes du programme de collaboration variait, mais dans l'ensemble, les équipes étaient heureuses d'y avoir participé et estimaient qu'il s'agissait là d'un effort précieux pour leur organisation.

- La collaboration a réussi à attirer l'attention sur les avantages d'une participation des patients et familles aux efforts d'amélioration de la qualité. Chaque équipe a impliqué des patients conseillers dans le projet, toutefois l'expérience a été différente d'une équipe à l'autre, principalement en raison de la nature du programme. Certains participants estimaient qu'il faudrait préciser et mieux structurer le rôle et l'objectif visés pour la participation des patients.

- L'évaluation de l'état de préparation préalable à la collaboration est utile pour avoir un aperçu des différentes situations de départ et pour documenter la disponibilité des données, et ce, afin d'éviter les hypothèses qui pourraient entraîner des retards.

- S'assurer que les équipes comprennent qu'il est tout aussi important d'identifier les occasions d'apprentissage émergentes que de définir et d'atteindre des objectifs d'amélioration plus ambitieux.

- Une approche plus structurée pourrait inclure des ressources telles qu'un guide ou du matériel de formation pour les équipes et pourrait prévoir des interventions visant à éliminer les obstacles à une plus grande participation des patients et des familles.

À la lumière des commentaires obtenus sur le premier volet, les suggestions d'amélioration pour le deuxième volet comprenaient l'élaboration d'une trousse pour le changement visant à partager les meilleures pratiques avec les nouvelles équipes (Box 1). Les suggestions portaient également sur l'accroissement de la formation et des ressources pour favoriser un engagement réel de la part des patients et familles.

\section{BOX 1.}

Trousse pour le changement

- II a été suggéré de mettre au point, pour les équipes participantes, une " trousse pour le changement " qui serait régulièrement mise à jour.

- Cela aiderait les nouvelles équipes à choisir les domaines prioritaires et à trouver des idées pour tester les changements.

- La trousse pourrait inclure des listes d'améliorations potentielles, des stratégies, des outils validés et des mesures de résultats que toute équipe pourrait appliquer.

L'Annexe 1 présente la liste des participants ainsi que leurs objectifs et les résultats obtenus.

\section{Deuxième volet collaboratif}

Le deuxième volet collaboratif pour l'amélioration de la sécurité des soins à domicile consistait en un programme d'apprentissage structuré pour faciliter la collaboration et l'application des connaissances afin de résoudre les problèmes de sécurité liés aux soins à domicile. Il y a eu des séances d'éducation portant sur des sujets liés à l'amélioration de la qualité dans le secteur des soins à domicile et sur la réalisation d'un projet pilote en matière de sécurité des patients. L'ensemble de la collaboration s'est déroulé virtuellement au moyen de sessions en ligne, de téléconférences et de salons de discussion en ligne. Ce volet s'est déroulé du 15 février 2017 au 21 février 2018. Un accompagnement facultatif était offert aux équipes intéressées pour une période supplémentaire de six mois.

Durant la première moitié de la collaboration, les sessions de formation ont été animées par des experts à tous les quinze jours environ. Après ces présentations, les participants organisaient une réunion en ligne pour discuter de leur apprentissage 
et formuler leurs questions. Les accompagnateurs répondaient immédiatement aux questions postées sur le centre de partage où était hébergé le matériel de collaboration. Dans l'évaluation du deuxième volet, la qualité de l'accompagnement a reçu une note moyenne de 5,78, la présentation, une note moyenne de 5,95, et les autres sources de matériel, une note de 5,61 (le tout sur une échelle de 1 à 7,7 étant la note la plus élevée). Voir le Box 2 pour une liste des forces et des défis identifiés au cours de l'évaluation.

\section{BOX 2.}

Forces et défis du deuxième volet de collaboration

Forces

- Accès aux outils d'amélioration de la qualité

- Voir d'autres approches d'amélioration de la qualité à l'œuvre

- Accès à l'expertise en accompagnement

- La qualité des présentateurs experts

- Capacité à se concentrer sur la réalisation d'un projet

- Possibilité de travailler en équipe

- Possibilité d'obtenir des commentaires de ses pairs à travers le pays

- Permettre aux équipes de choisir leurs propres thèmes pour les projets pilotes

- Capacité à exploiter des ressources collaboratives

\section{Défis}

- Trouver l'équilibre en fonction des autres priorités de travail

- Pressions ou manque de temps

- Implication insuffisante de la part de certains promoteurs de projet

- Planification et préparation initiales inadéquates de la part des équipes

- Difficultés à définir une idée de projet ou un énoncé des objectifs

- Accorder plus de temps aux présentations individuelles lors de la réunion finale

- Difficultés d'utilisation du centre de partage d'informations

- On n'utilise pas suffisamment les données dans le secteur des soins à domicile

Les participants au premier volet comprenaient la Croix-Rouge canadienne (Cornwall), Saint Elizabeth Health Care, l'Office régional de la santé de Winnipeg, VHA Home HealthCare et Eastern Health Authority (T.-N.). Quant au deuxième volet, sept organisations de soins à domicile y ont participé : Beacon Community Services (C.-B.), Care at Home Services (C.-B.), Groupe santé CBI (pancanadien), Centre d'accès aux soins à domicile et en milieu communautaires du Réseau local d'intégration des services de santé du Centre-Ouest $(\mathrm{ON})$, Régie de la santé de la Nouvelle-Écosse (N.-É.), Vancouver Island Health Authority (C.-B.) et VHA Home HealthCare (ON). L'organisation Spectrum Health $(\mathrm{ON})$ a commencé le projet de collaboration mais a rapidement mis fin à sa participation en raison de priorités organisationnelles contradictoires.

Les projets ciblaient un large éventail de type des clientèle et d'exigences en matière de soins, notamment les soins axés sur les clients pour les personnes atteintes de démence, la surveillance des infections et la gestion des perfusions centrales et périphériques, la réduction de l'impact négatif des chutes répétées et l'amélioration de la documentation pour les interventions en cas de chutes signalées. L'Annexe 2 présente une liste des organisations de soins à domicile et de leur projet dans le cadre du deuxième volet.

Le deuxième volet collaboratif a été perçu, dans l'ensemble, comme une réussite et une progression par rapport au premier volet. Pour ce qui est du temps consacré au deuxième volet du projet collaboratif, $33 \%$ des participants ont déclaré y avoir dédié moins de 10 heures par mois, $28 \%$, de 11 à 20 heures par mois, $33 \%$, de 21 à 40 heures et $6 \%$, plus de 40 heures (Figure 1). Environ $72 \%$ des participants ont indiqué avoir alloué "le temps adéquat " au projet, $22 \%$ estiment y avoir dédié trop peu de temps et les $6 \%$ restants déclarent avoir consacré trop de temps à l'initiative.

\section{FIGURE 1.}

Temps consacré au projet collaboratif (heures/mois)

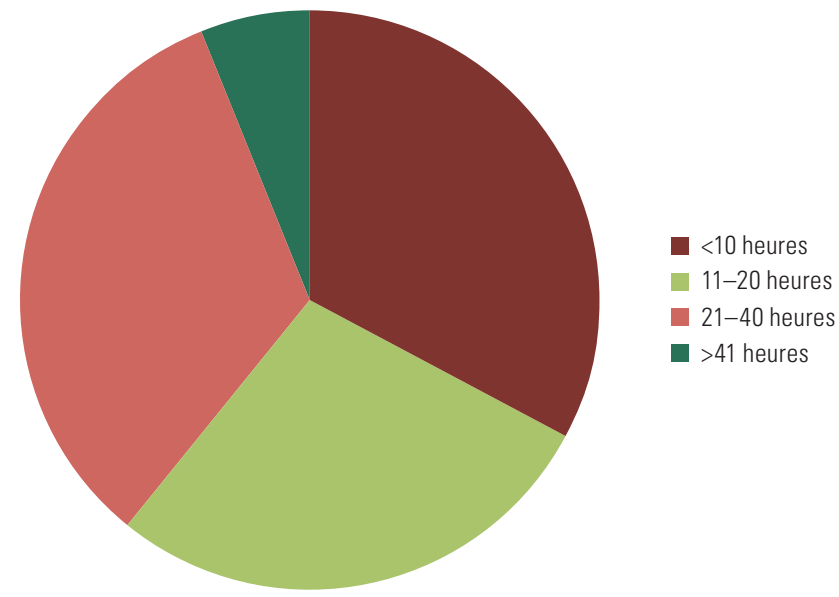

Le deuxième volet a été conçu pour encourager la collaboration interprofessionnelle au sein des équipes et l'apprentissage entre elles. Les présentations des experts ont porté sur les thèmes de la collaboration interpersonnelle et de la création d'équipes efficaces. Les équipes ont eu maintes occasions de présenter diverses étapes de leurs projets pilotes à tous les participants, de recevoir des commentaires et de se familiariser avec le travail réalisé par les autres équipes. La plupart des participants se sont montré plutôt positifs dans leur évaluation globale de la collaboration. Un des participants a indiqué que "c'était une expérience positive qui a mené à des améliorations tant pour l'équipe que pour l'organisation ".

Plusieurs participants ont indiqué, comme impacts positifs, l'accès aux outils et à la méthodologie d'amélioration de la qualité ainsi que l'observation des autres démarches d'amélioration de la qualité. Un des participants a déclaré que 
" l'accompagnement offrait un niveau de consultation et d'expertise qui n'aurait pas été habituellement accessible dans notre organisation ». Un autre participant s'est dit « inspiré par les nombreux conférenciers invités et leur travail».

Quant au taux de satisfaction à l'égard de la collaboration dans son ensemble, $87,5 \%$ des répondants ont accordé une note supérieure ou égale à 5 (sur une échelle de 1 à 7,7 étant la note la plus élevée), pour une note moyenne de 5,46. La plupart des participants ont indiqué que cette collaboration les aiderait à se conformer à d'éventuelles normes d'agrément. Quelque $50 \%$ des répondants ont indiqué qu'ils participeraient à nouveau à ce type de projet et $73 \%$ ont indiqué qu'ils recommanderaient à leur organisation de participer à une initiative du genre.

\section{Conclusion}

Les participants ont vu de manière positive les aspects clés des projets collaboratifs, notamment la qualité de l'accompagnement, la qualité des conférenciers experts et le niveau d'apprentissage intra-équipe et inter-équipe. Le deuxième volet a été généralement perçu comme une amélioration par rapport au premier volet. Permettre aux équipes de choisir leur propre domaine de sécurité constitue l'une des forces du deuxième volet.

Les recommandations à prendre en compte pour d'éventuels projets sont, notamment, les suivantes : impliquer davantage les promoteurs de projet dans le processus, prévoir jusqu'à trois réunions pour favoriser la connexion entre les équipes et avec les accompagnateurs, favoriser davantage l'implication des patients et des familles, consacrer plus de travail, avant le début de la collaboration, pour l'identification des thèmes et pour mieux connaître l'état des capacités face au projet proposé et, finalement, étendre la durée de la collaboration à 18 mois pour permettre d'achever les projets.

L'ICSP et l'ACSSD continueront à œuvrer pour rendre les soins à domicile plus sécuritaires et proposeront aux fournisseurs de services le contenu et les ressources créées dans le cadre de ces projets afin d'aider les organisations de soins à domicile qui souhaitent accroître leurs capacités d'amélioration de la qualité des soins et de la sécurité des patients. HQ

\section{Références}

Veuillez vous reporter à la liste dans la version anglaise (pp. 104-105).

\section{À propos des auteurs}

Wayne Miller, B.Ens., B.Sc. (éducation), M.Sc., est gestionnaire principal de programme à l'Institut canadien pour la sécurité des patients et responsables d'initiatives pour la sécurité des soins à domicile.

Maaike Asselbergs est membre de Patients pour la sécurité des patients au Canada. Elle a été membre du groupe de travail sur la sécurité des soins à domicile dans le cadre du Consortium national sur la sécurité des patients.

Jeanne Bank dirige le projet "Réseau de savoir " à l'Association canadienne des soins et services à domicile. Elle a de l'expérience en gestion de projets et de programmes portant sur la santé, la sécurité et les politiques sociales. Elle est spécialiste des normes aux niveaux national et international.

Mike Cass est gestionnaire principal de programme à I'Institut canadien pour la sécurité des patients. II a dirigé des projets nationaux d'amélioration de la sécurité ainsi que des collaborations en matière d'amélioration de la sécurité des médicaments, de prévention des chutes et d'amélioration de la qualité des soins à domiciles.

Virginia Flintoft, B.Sc.inf., M.Sc., est gestionnaire principale de programme à l'Institut d'évaluation, de gestion et de politiques en santé (Université de Toronto). En tant que spécialiste des mesures et de l'évaluation et gestionnaire de l'équipe responsable des mesures à l'Institut canadien pour la sécurité des patients, elle participe à de nombreuses initiatives pour l'amélioration de la qualité.

Nadine Henningsen est directrice générale de l'Association canadienne des soins et services à domicile. À ce titre, elle dirige une association dynamique qui se consacre à l'excellence des soins à domicile au moyen du leadership, de la sensibilisation, de la représentation et du savoir.

Adresse pour correspondance : Wayne Miller, gestionnaire principal de programme, Institut canadien pour la sécurité des patients; téléphone : 709-730-0864; courriel : wmiller@cpsi-icsp.ca. 